\title{
ONLINE PLATFORMS AS MODERN TOOLS IN TOURISM IN EXTRAORDINARY TIMES: CASE FOR FURTHER DIGITALIZATION IN WESTERN BALKANS
}

\author{
Vesna Lukovic ${ }^{1}$ (D)
}

DOI: https://doi.org/10.31410/tmt.2020.555

\begin{abstract}
Extraordinary times require an extraordinary response, especially when economic growth is at stake. Tourism contributes to economic growth in Western Balkans and has been robust in recent years. That was supported by new business models which make it possible for households to participate in the digital economy, including online platforms for travel accommodation. Internet connectivity and digital skills are crucial in that respect. This paper looks at the convergence of the Western Balkan candidate countries to the European Union (EU) in terms of connectivity and the digital skills needed. Analysis of data derived from questionnaires and other sources at the Eurostat show that candidate countries participate in the collaborative economy less and are below EU average in terms of digitalization. Investments supported by EU commitment to the region could improve internet connectivity and digital skills in the Western Balkans. That would benefit their economies which is especially relevant now considering the Covid-19 outbreak in the first quarter of 2020 and its disruption to achieving many goals. The argument for further digitalization is even more important.
\end{abstract}

Keywords: Digitalization, Tourism, Economics, Digital single market, Western Balkans, Management tools.

\section{INTRODUCTION}

$\mathrm{T}$ ourism represents over $10 \%$ of gross domestic product (GDP) and supports about 330 million jobs globally (World Travel and Tourism Council (WTTC), 2020). Tourism of today is considerably more influenced by the internet and information technology than ever before. With the development of digital technology and the internet, tourists and other travellers can now find various information, accommodation and other services online. They can compare and review options from different accommodation providers and their search can be completed in seconds and without costs.

Following European Commission's (EC) initiative for an all-inclusive digital society (2007), the EU's Digital Single Market aims to ensure access to the internet throughout the EU to encourage participation in the digital economy and society. Regarding tourism, the aim is to boost digitalization and to enhance investment in the tourism sector through the better use of available EU financing opportunities. The principles of the EU's digital single market are important for countries that are in the process of accession to the EU as well. Digitalization and listing spare dwellings on digital platforms for short-term stays can be an important source of revenue, not only in the EU but also in the Western Balkans. Further digitalization in this region is thus important. The importance is two-fold, not just as a matter of improving local economies, but also as a step towards convergence to the EU regarding its digital single market ${ }^{2}$.

\footnotetext{
$1 \quad$ Dimitsanas 24/26, Kato Toumpa 54454, Thessaloniki, Greece

2 For more details on the Digital Single Market see https://eufordigital.eu/discover-eu/eu-digital-single-market/
} 
This research had been guided by concepts associated with digital technology and its impact on economic activity. There is a strong correlation between tourist arrivals and employment and GDP. Research has confirmed that tourism has a positive impact on economic growth (Faber and Gaubert, 2019). The analysis incorporates a general view that the digital economy can help generate growth (European Central Bank, 2018) and that online-platforms can bring additional tourist revenue (International Monetary Fund (IMF), 2018). The study looks at the level of internet access at home, meaning that the internet is accessed at home by any device (e.g. desktop computer, laptop, telephone, tablet, mobile or smartphone, etc). The assumption is that in order to be able to participate in online platforms for short-term accommodation successfully, households need internet access at home. Listing a dwelling on an online platform implies a series of activities such as information about the accommodation, pricing, updating and upgrading privacy and other policies of the accommodation, providing information and assistance to travelers in terms of directions, maps, and similar. Internet access at home, by any device, is thus considered necessary in this research.

\section{LITERATURE REVIEW}

Research has confirmed that tourism has a positive impact on economic growth (Faber and Gaubert, 2019). Tourism has been increasingly influenced by new technologies and digitalization. Newer research has found that the potential benefits of digitalization are high (Charalabidis et al, 2015; Parviainen et al, 2017). One of the benefits is that by digitizing information-intensive processes costs can be cut by up to $90 \%$ (Marcovitch and Willmott, 2014). On the other hand, digitalization has a proven impact on reducing unemployment (Parviainen et al, 2017) which is of high importance to the Western Balkans. Digitalization is typically understood as the adoption or increase in the use of digital or computer technology by an organization, industry, country, etc. IMF's definition of digitalization is that it "encompasses a wide range of new applications of information technology in business models and products that are transforming the economy and social interactions." (IMF, 2018, p.1).

Academics have established that digitalization is transforming the world not only in terms of socializing, traveling and sharing information but also in terms of working and new business models (Bouwman et al, 2017), such as "collaborative" or "sharing" economy. "Sharing economy" has no single definition (Goeroeg, 2018). However, in regard to accommodation rentals, common to all definitions is that it is a peer-to-peer system, where companies use online platforms to connect people who have a spare dwelling with people who are searching for accommodation. IMF found that "platforms such as Airbnb have enabled the rapid growth of shortterm rentals in some economies, particularly those with a tourism industry, suitable housing stock, and a favorable legal environment" (IMF, 2018, p.25).

Online "sharing economy" platforms typically lead to reduced costs for travellers compared to hotels (Bivens, 2018) and on the other hand, generate revenue for owners of properties (Mao et al, 2018). In contrast to hotels, online platforms enable travellers to rent a wider range of accommodation-types, from rooms to bungalows, villas, etc. It is no wonder then that online platforms such as Booking.com, Airbnb, HomeAway and others have been embraced by households because those platforms mean new opportunities for revenue (Clancy, 2018). Digitalization has been included in policy strategies in many countries, not just because it has a positive impact on economic growth and GDP per capita (Sabbagh et al, 2013; ECB, 2019) but because it improves the digital literacy of the population as well. To be able to actively participate in the society and 
digital economy, access to technologies and services must be affordable, as well as the ability and skills to use them.

Regarding the Western Balkans, it seems the governments have still not recognized the potential of digitalization in tourism and the adaptation of new technologies and applications as a tool to transform domestic tourism (Dugalić and Lazarević, 2018).

\section{METHODOLOGY}

This research looks at digitalization from the viewpoint of internet connectivity and digital skills to use the internet. Internet, the system of interconnected computer networks, is in this paper analyzed from the perspective of internet access, meaning that the term access to the internet includes all types of internet connectivity (dial-up, fixed broadband, mobile broadband, etc.). Wired technologies most commonly used to access the internet are divided between broadband and dial-up access over a normal or an ISDN telephone line. Broadband lines are defined as "having a capacity higher than ISDN, meaning equal to or higher than $144 \mathrm{kbit} / \mathrm{s} . "$ (Eurostat, 2019, p.13).

In terms of connectivity, the analysis looks at the level of internet access at home, meaning that the internet is accessed at home by any device (e.g. desktop computer, laptop, telephone, tablet, mobile or smartphone, etc). The assumption is that in order to be able to participate in online platforms for short-term accommodation, households need internet access at home. Listing a dwelling on an online platform implies a series of activities such as updating information about the accommodation, pricing, updating and upgrading privacy and other policies of the accommodation, providing information and assistance to travelers in terms of directions, maps, and similar. An accommodation provider has to have internet access to be able to undertake all communication with guests and to successfully conduct all segments of the booking and payment processes. All that typically means more than just an occasional ten-minute work engagement on a mobile smartphone or other portable devices. Internet access at home, by any device, is thus considered necessary in this research. In terms of households, Eurostat's ICT questionnaires included all types of households (single person, single person with dependent children, two adults, two adults with dependent children).

Data for research have been derived from Eurostat's statistical data warehouse and EC's special surveys and reports ${ }^{3}$. Predominant sources of data have been Eurostat's surveys on information communication technology (herafter:ICT) usage in households and by individuals. Eurostat's secondary statistics indicators on the ICT sector and ICT specialists were also used for analysis. Surveys that are taken periodically in policy areas where official statistics are not always available were also explored. Macroeconomic data for Western Balkans were taken mostly from the IMF and the Eurostat. Other reports and assessments from specialist organizations and EU bodies regarding digitalization have been also analyzed and reviewed.

Research methods are descriptive and quantitative. The descriptive part explains the meaning of various variables and the logic behind indicators which are based on the responses to questionnaires and surveys submitted to the Eurostat. ${ }^{4}$ Quantitative methods are used to analyze

\footnotetext{
$3 \quad$ All figures and tables in this analysis have been prepared by the author, based on data in Eurostat's and IMF's databases available as of September 2020.

$4 \quad$ See relevant explanations in Eurostat (2019), Eurostat (2020a) and Eurostat (2020b).
} 
data directly derived from the mentioned questionnaires and surveys. With quantitative methods using statistical analysis, digitalization is analyzed from the connectivity perspective while also looking at the digital skills and the use of collaborative economy in the Western Balkans in regard to short-stay tourist accommodation. Some comparisons have been done vis-à-vis the average of the EU as candidate countries have been also analyzed from the perspective of their convergence in digitalization towards the average of the EU. The Western Balkan candidate countries analyzed are Albania, North Macedonia, Serbia and Montenegro. Many data for Albania have not been available in Eurostat's database related to ICT, so Albania is included in this research only to the extent of the availability of data.

\section{ACCESS TO INTERNET AND DIGITAL SKILLS}

The EU strategy has been based on improving access "for consumers and business, on creating the right conditions for digital networks and on maximizing the growth potential of the digital economy" (European Parliament, 2019, p.11). Part of the EU strategy was to roll-out ultrafast connectivity to homes in every EU region so that "rural areas can also have better mobile coverage and fast internet" (European Parliament, 2019, p.43). The principles of the EU's digital single market are important for countries that are in the process of accession to the EU as well because "fast and secure digital connectivity is an essential element of the reforms required for creating a market- and investment-friendly environment in the Western Balkans." (European Commission, 2019, p.1) Under the initiative of the EC, the EU and the Western Balkans partners have started a process to boost connectivity in the region and improve access to the digital economy and society. That was part of the Strategy for the Western Balkans from February 2018. The strategy supported the deployment of broadband and a roadmap to lower roaming costs.

Internet connectivity in the Western Balkans candidate countries is below the EU27 average 5 (Figure 1) although there has been an improvement since 2015 when only $69 \%$ of households had access to the internet at home in North Macedonia and 64\% in Serbia. In 2019 both countries recorded an increase in internet access at home as it reached $82 \%$ in North Macedonia and $80 \%$ in Serbia. In Montenegro, there were only $55 \%$ of households with access to the internet in 2012 but that percentage climbed to $72 \%$ in 2019. It must be emphasized that Eurostat data about internet connectivity are collected annually by national statistical authorities applying various methods but based on Eurostat's model questionnaire ${ }^{6}$ on the use of ICT in households and by individuals. The 2019 Eurostat questionnaire had two questions in terms of connectivity and their answers were directly converted to the data presented below. The first module of the questionnaire was module A (Access to Information and Communication Technologies) and the first question, was

"A1. Do you or anyone in your household have access to the internet at home? (by any device)".

The second question in module A of the ICT survey was

"A2. What types of internet connections are used at home? (tick all that apply)

\footnotetext{
EU27 means EU from 2020 onwards

6 The exact title of the survey is Community Survey of ICT Usage in Households and by Individuals. For detailed explanation see Eurostat meta data at: https://ec.europa.eu/eurostat/cache/metadata/en/isoc_i_esms.htm
} 


\subsection{Broadband connections}

a) Fixed broadband connections, e.g. DSL, ADSL, VDSL, cable, optical fibre, satellite, public Wi-Fi connections

b) Mobile broadband connections (via the mobile phone network, at least 3G, e.g. UMTS, using (SIM) card or USB key, mobile phone or smart phone as a modem)"

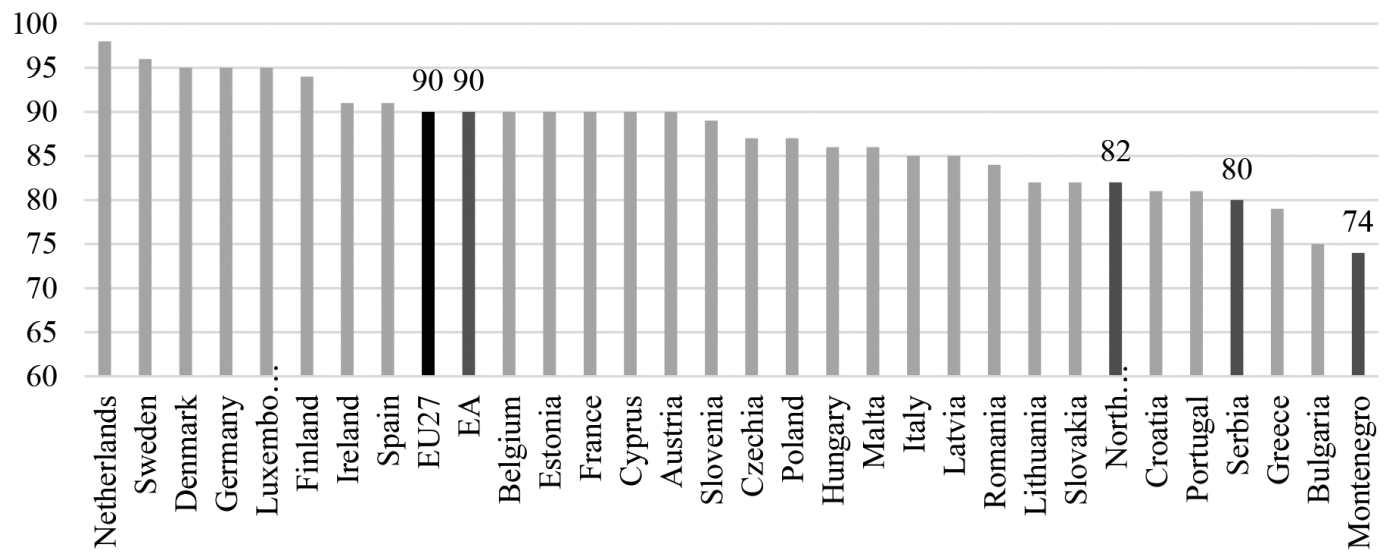

Figure 1. Percentage of households that answered that they had internet access at home (by any device) in 2019

Source: Eurostat, 2020
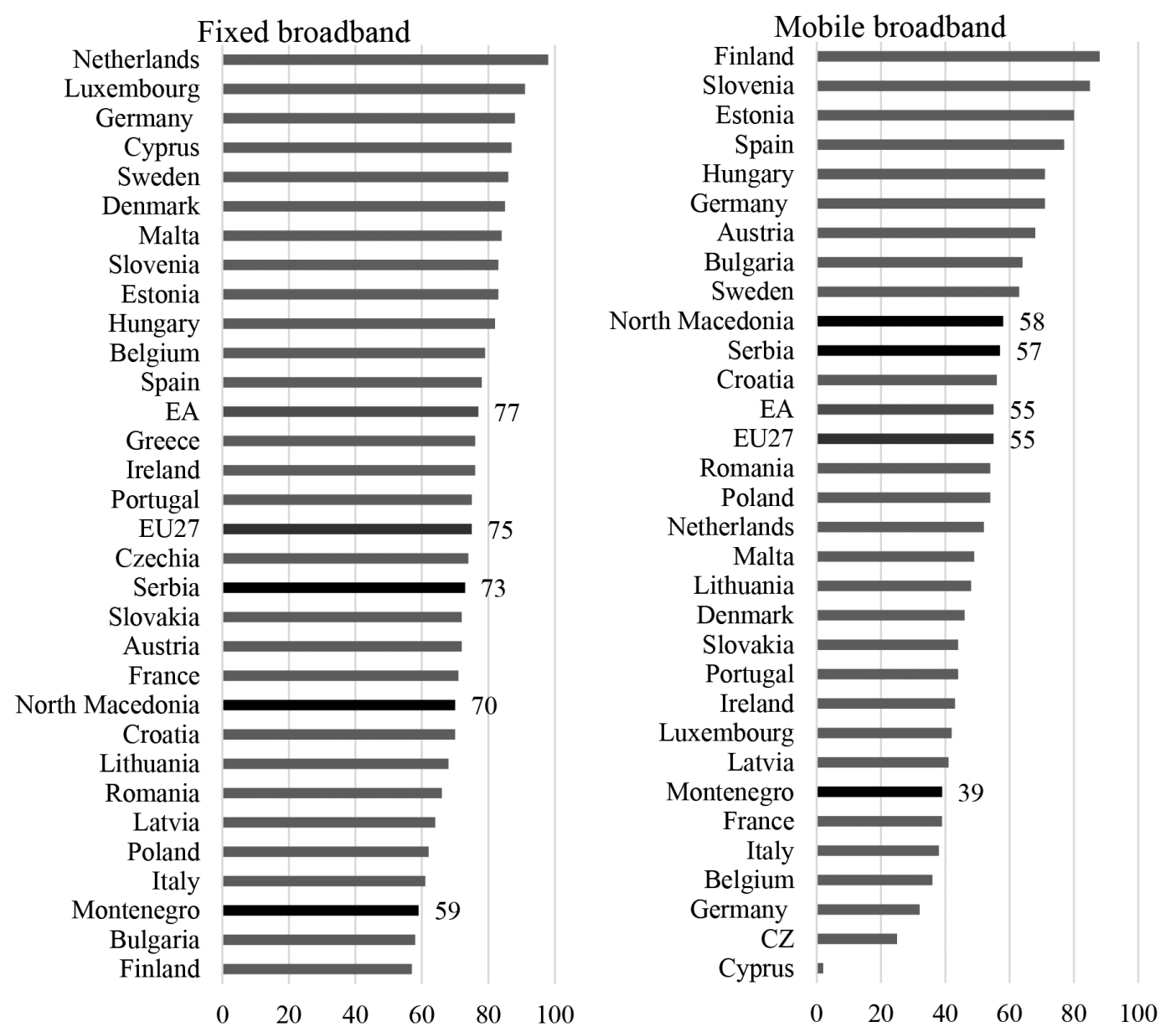

Figure 2. Percentage of households with fixed and/or mobile broadband at home in 2019

Source: Eurostat, 2020 
In terms of the type of internet connection (Figure 2), $73 \%$ of households in Serbia had fixed broadband and 57\% had mobile broadband at home in 2019. In Montenegro, the percentage of households with fixed broadband was $59 \%$ and with mobile broadband $39 \%$, while in North Macedonia the percentage was $70 \%$ and $58 \%$ in 2019, respectively. Candidate countries from the Western Balkans are below the EU average in terms of digital skills as the majority of households answered that they had low and basic digital skills (Figure 3).

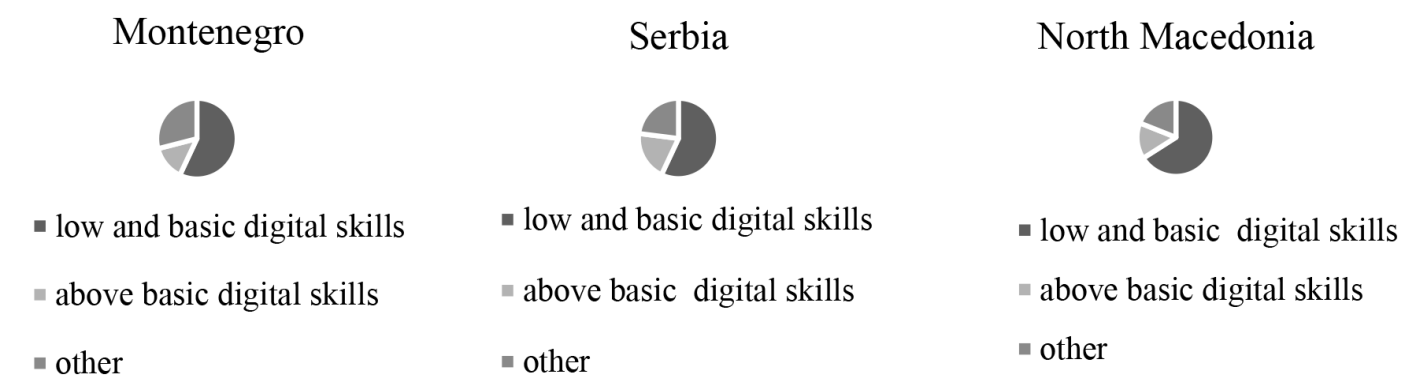

Figure 3. Composition of digital skills in Western Balkan candidate countries, $2019^{7}$

Source: Eurostat, 2020

In order to be competitive in a new digital world, being connected to the internet is not enough, digital skills are needed as well. The percentage of households that answered to the Eurostat's ICT questionnaire that they do not have the internet at home because of the lack of skills has been falling over the years, but candidate countries from the Western Balkans are still below the EU27 average in terms of individuals who have above basic digital skills (Figure 4).

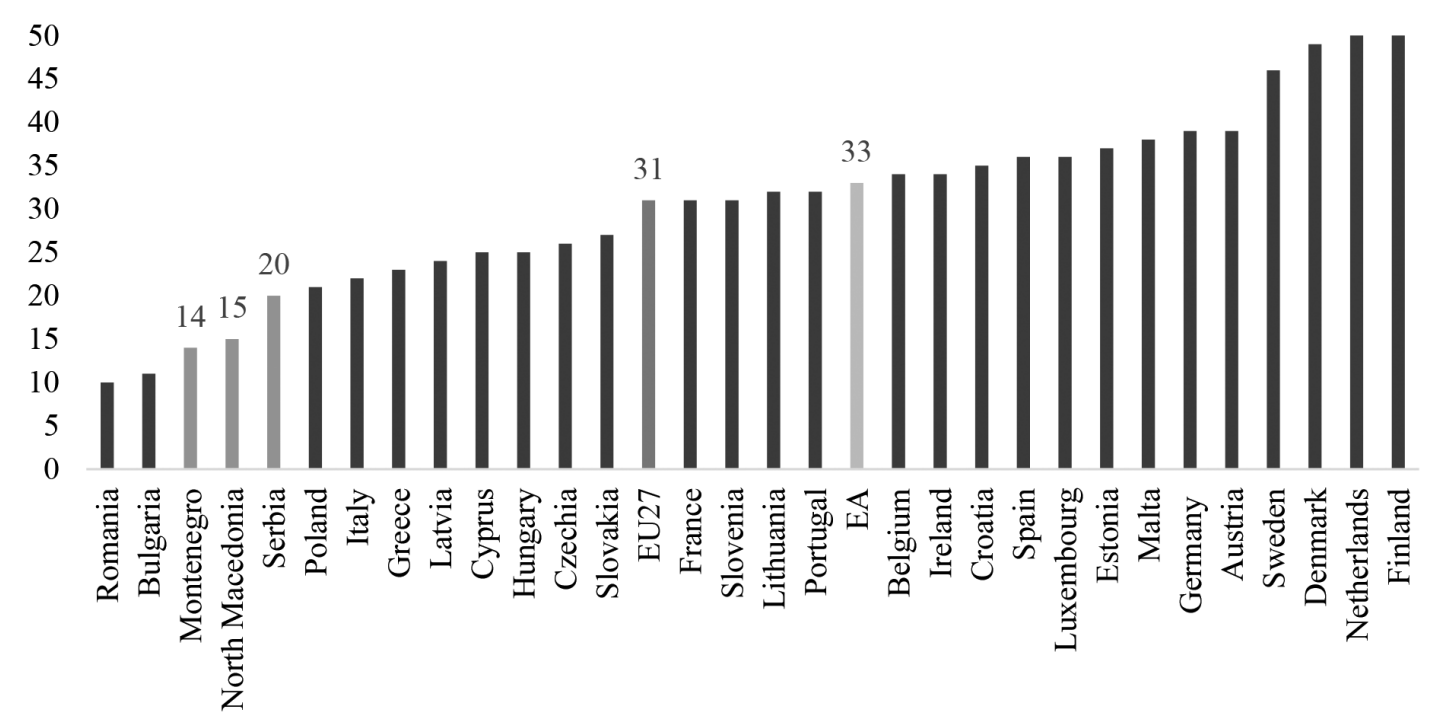

Figure 4. Closing the gap: Western Balkans vs. EU.

Percentage of individuals who have above basic digital skills, 2019

Source: Eurostat, 2020

\section{EU ASSISTANCE IN DIGITALIZATION IN WESTERN BALKANS}

The EU can and should help the Western Balkans to close the gap vs EU countries regarding digitalization considering that access to fast and ultrafast broadband is a necessary condition for competitiveness (European Commission, 2020) and being competitive is one of the features needed in the accession process. General financial and technical assistance for candidate

The newest available data for Montenegro is 2017. The same figure is a proxy for 2019. 
countries (Albania, Serbia, Northern Macedonia and Montenegro) has been available under the Instrument for Pre-accession Assistance (IPA). IPA II ${ }^{8}$ (2014-2020) has a strategic focus for each country for the 7 years. In country strategy papers priorities were set out for EU financial assistance to support candidate countries on their path to the EU. The strategies translate political priorities from the enlargement policy framework into areas where financial assistance is most useful to meet the accession criteria. IPA II targets sectors that can bring candidate countries closer to EU standards in terms of institution- and capacity- building, reforms focused on socio-economic and regional development; reforms focused on employment, social policies, education, promotion of gender equality, and human resources development; capacity building in agriculture and rural development, and regional and territorial cooperation. Under the IPA II financial assistance in terms of country allocation for 2014-2020, indicative funding allocation for Serbia was $€ 1.539,1$ billion, for Montenegro $€ 279.1$ million (not including the allocation for cross-border cooperation), for North Macedonia € 608.7 million and Albania $€ 639.5$ million.

However, it seems that there has been some new awareness about the importance of digitalization in recent years. On 6 February 2018 the Digital Agenda for Western Balkans was presented as one of the six flagship initiatives in the Communication on a Credible Enlargement Perspective for Enhanced EU engagement with the Western Balkans (EC, 2018) ${ }^{9}$. In April 2018, an EU commitment to launching the Digital Agenda was declared during the Western Balkans Digital Summit. The Digital Agenda included a roadmap for lowering roaming charges between the EU and Western Balkans partners. The Digital Agenda for Western Balkans is about the EC working with six Western Balkan partners (Albania, Bosnia and Herzegovina, Kosovo, Montenegro, Northern Macedonia and Serbia) in order to invest in broadband connectivity. The commitment is in line with the fact that good digital infrastructure is essential for the roll-out of broadband in the Western Balkans. To deploy broadband infrastructure in the region $€ 30$ million in EU grants has been pledged to be available ${ }^{10}$ under the Western Balkan Investment Framework. As one of the first investment packages, it was a technical assistance package for Albania that had been approved first.

The Digital Agenda for the Western Balkans is expected to support the digitalization of industry in the Western Balkans to ensure that all sectors benefit from digital innovations. This includes not only supporting eGovernment, eProcurement and eHealth tools but also helping improve digital skills by providing opportunities for students and young people to acquire coding and other digital literacy skills. The idea also was that the Digital Agenda could help set up national research facilities and integrate them in the digital European Research Area. This is particularly important now as there are many uncertainties regarding travel due to the corona-virus outbreak. As a result, by integrating national research facilities digitally, world-class training for a new generation of researchers and engineers could be brought together, thereby promoting interdisciplinary collaboration.

In addition to all of the above, on 6 October 2020, the EC adopted an Economic and Investment Plan for the Western Balkans ${ }^{11}$ to support the economic recovery and convergence to the EU. The plan is expected to mobilise up to $€ 9$ billion and support human capital, competitiveness and inclusive growth, sustainable connectivity and green and digital transition. Digital transition will be supported by the roll-out of broadband infrastructure.

8 Details on the legal framework see https://ec.europa.eu/neighbourhood-enlargement/instruments/overview_en

$9 \quad$ For more details see Communication on a Credible Enlargement Perspective for Enhanced EU engagement with the Western Balkan: https:/ec.europa.eu/commission/sites/beta-political/files/communication-credible-enlargement-perspective-western-balkans_en.pdf

10 See Press Release https://ec.europa.eu/commission/presscorner/detail/en/IP_18_4242

11 For more details, see https://ec.europa.eu/commission/presscorner/detail/en/ip_20_1811 


\section{IMPORTANCE OF TOURISM AND ONLINE PLATFORMS}

Some candidate countries in the Western Balkans rely on tourism more than others. According to data from WTTC (2020) the importance of the tourism industry in Montenegro can be explained by the impact of international visitors which was $€ 1,132$ million in 2019 in visitor spend, about $47.7 \%$ of total exports. Tourism and travel are also important in Albania as it contributes about one fifth to the GDP. On the other hand, Serbia and North Macedonia are less reliant on tourism receipts compared to the other two candidate countries. In Serbia, international visitor impact in visitor spending was $7.0 \%$ of total exports while in North Macedonia international visitor spend was $4.9 \%$ of total exports in 2019 (WTTC).

Table 1. Arrivals at tourist establishments - total: hotels, holiday

and other short-stay accommodation, camping grounds, recreational grounds and trailer parks

\begin{tabular}{|l|c|c|c|}
\cline { 2 - 4 } \multicolumn{1}{c|}{} & $\mathbf{2 0 1 7}$ & $\mathbf{2 0 1 8}$ & $\mathbf{2 0 1 9}$ \\
\hline Montenegro & 843.609 & 959.121 & $1,167.968$ \\
\hline North Macedonia & 624.853 & 702.833 & 755.438 \\
\hline Serbia & $1,496.301$ & $1,709.961$ & $1,845.562$ \\
\hline
\end{tabular}

Source: Eurostat, 2020

Table 2. Arrivals at tourist establishments: holiday ${ }^{12}$ and other short-stay accommodation

\begin{tabular}{|l|c|c|c|}
\cline { 2 - 4 } \multicolumn{1}{c|}{} & $\mathbf{2 0 1 7}$ & $\mathbf{2 0 1 8}$ & $\mathbf{2 0 1 9}$ \\
\hline Montenegro & 42.093 & 37.993 & 37.980 \\
\hline North Macedonia & 22.019 & 24.157 & 25.514 \\
\hline Serbia & 149.729 & 184.956 & 210.252 \\
\hline
\end{tabular}

Source: Eurostat, 2020

With the change in how tourists plan their holidays, supported by information-communication technology in recent years, online platforms such as Airbnb, Booking.com and others have boomed locally, regionally and globally in the last decade. Online platforms for accommodation generate revenue for owners of properties (Mao et al, 2018, Clancy et al, 2018). These online platforms have been also welcomed in the Western Balkans as the number of establishments for holiday and other short-stay accommodation has risen sharply in the last few years.

Serbia had the most spectacular rise of establishment for holiday and other short-stay accommodation from 2014 to 2018, while Montenegro followed with 15.4\% growth between 2016 and 2018 and North Macedonia recorded an increase of 5.6\% between 2016 and 2019 (Eurostat, 2020). In line with the worldwide boom in tourism in the last few years, there has been an increase in arrival at all tourist establishments (Table 1), including at holiday and other short-stay accommodation (Table 2) in Western Balkan candidate countries.

Most of the short-term travel accommodation services are booked through websites such as online platforms Booking.com, Airbnb, HomeAway, VacationRentals and similar that provide

12 Eurostat's definition of holiday and other short stay accommodation is "accommodation, typically on a daily or weekly basis, principally for short stays by visitors, in self-contained space consisting of complete furnished rooms or areas for living/dining and sleeping, with cooking facilities or fully equipped kitchens. This may take the form of apartments or flats in small free-standing multi-storey buildings or clusters of buildings, or single storey bungalows, chalets, cottages and cabins. Very minimal complementary services, if any, are provided." Holiday and other short stay accommodation excludes "provision of furnished short-stay accommodation with daily cleaning, bed-making, food and beverage services". It also excludes "provision of homes and furnished or unfurnished flats or apartments for more permanent use, typically on a monthly or annual basis" (Eurostat, 2020b) 
dedicated websites, i.e. online platforms, where travellers can access tourist services directly from other individuals. However, tourists and other travelers may also use other websites or applications to arrange accommodation from another individual (Figure 5), such as social networks (e.g.Facebook) where individuals and companies can advertise their accommodation as well (Eurostat, 2020). In 2019 about $21 \%$ of all individuals in the EU27 used any website or application to arrange accommodation and $17 \%$ used dedicated websites and applications to arrange an application from another (private) individual during the preceding 12 months (Eurostat, 2020). A similar trend of the "collaborative" economy has been seen in the Western Balkans in recent years too. The percentage of individuals using any website or application to arrange accommodation from another private individual was $15 \%$ in Serbia while in Montenegro and North Macedonia they were $14 \%$ and $13 \%$ in 2019 , respectively. In Serbia $11 \%$ of individuals used only dedicated websites or applications to arrange accommodation from another individual. In Montenegro, $13 \%$ of individuals use dedicated websites to arrange accommodation and in North Macedonia, only $4 \%$ of individuals used dedicated websites or applications to arrange accommodation from another individual in 2019 (Eurostat, 2020).

Data analysis shows that candidate countries of Western Balkan still have a lot to do to converge to the EU average not only in terms of connectivity and digital skills but also concerning the collaborative economy. In line with the above rests the economic case for further digitalization. Digitalization has been included in policy strategies in many countries, including the EU as a whole. Digital platforms can create new occupations and new jobs. The impact of digitalization in tourism is not just about participating in the digital economy for holiday and other short-term stay accommodation, digitalization can also help connected businesses and other businesses to expand. Also, digital technology has changed the terms of work with the rise to more short-term work instead of standard long-term contracts which are not so easy to come by in the Western Balkans. New business models - online platforms - have enabled clusters of tourist-related-businesses to form, and if listing a property on online platforms does not require significant investments, it can contribute to the households' income assuming that the internet's deployment and adoption of internet-enabled digital services and products can be delivered to households under reasonable cost provisions.

Low communication costs and search costs over the internet are, therefore, interesting for both, travelers and property owners. From a household's perspective then, by listing a spare dwelling at platforms such as Airbnb and others, a household's disposable income can increase and thereby in macro-economic terms, add to the GDP. That is in line with research that has established digitalization means a positive impact on economic growth per capita and GDP (Sabbagh et al, 2013). Another economic argument for further digitalization is related to taxation and the state budget. An increase in participation in online platforms, leading to more tourist arrivals to the country, also improves fiscal receipts by the state, leading to the alleviation of the burden on the public budget. Besides, digitalization may create new jobs and improve unemployment rates which are still rather high in the Western Balkans (Figure 6).

In line with the above, there is a strong argument for further digitalization and households' participation in the digital economy in terms of financial resources available for digitalization. The EC's digital strategy for the Western Balkans from 2018 is an incentive for countries in the region to prepare projects that would bring internet to remote and mountainous regions (for which tourist demand is rising) while also providing faster and ultra-fast internet access elsewhere in the Western Balkans. 


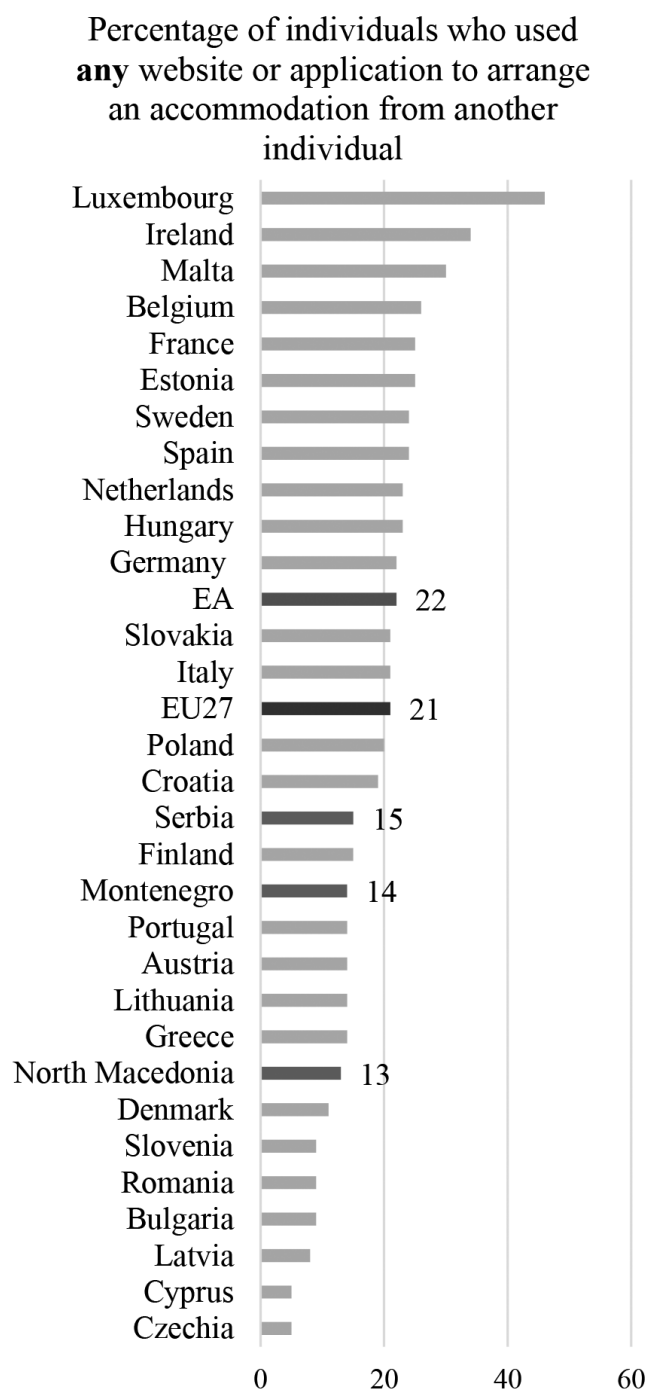

Percentage of individuals who used

dedicated websites or applications to arrange an accommodation from another individual

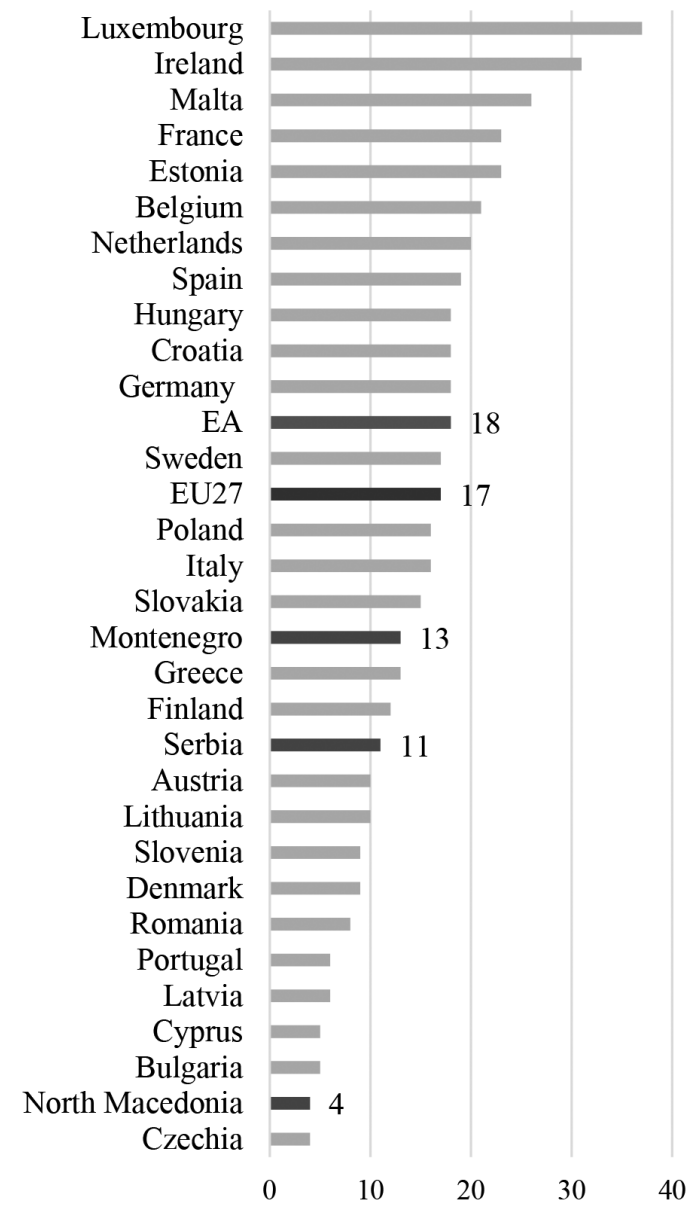

Figure 5. Collaborative economy in 2019: Western Balkan candidate countries vs EU

Source: Eurostat, 2020

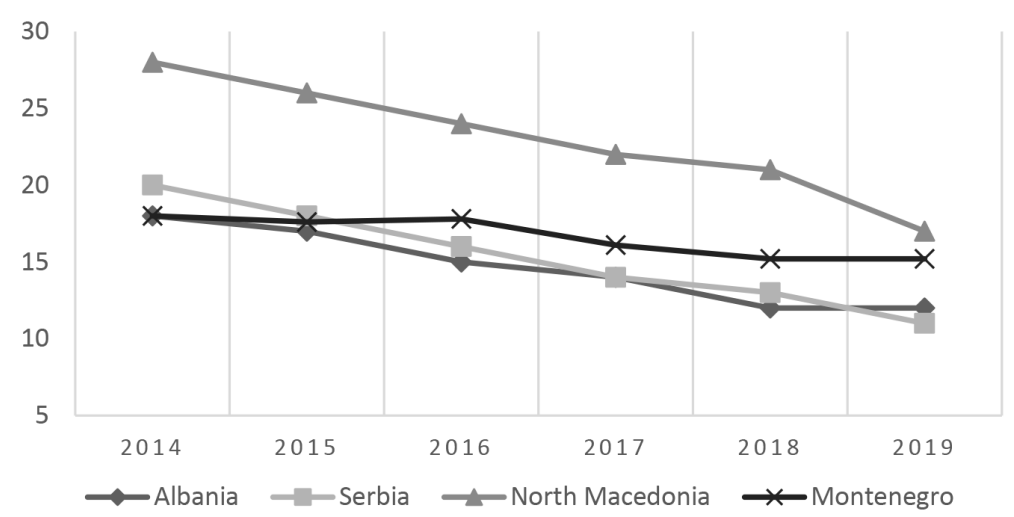

Figure 6. Unemployment rate (\%) in candidate countries of the Western Balkans

Source: Eurostat, IMF, 2020

External imbalances are another important challenge in all candidate countries from the Western Balkans. They all have relatively large current account deficits (Figure 7) due to much higher imports than exports of merchandise. Exports of services and secondary income cannot fully offset the deficits in merchandise trade. 
The relation between tourism and unemployment is that tourism influences not only accommodation services for visitors but also the food and beverage industry and railway, road, water and air passenger transport. The impact of tourism is also felt in demand for entertainment, cultural and other activities. Attracting more tourists and other travelers to the country and being able to offer them competitive and sustainable tourist services does not only help domestic labour markets and increase employment but also contributes to the growth of services exports and reducing current account deficits.

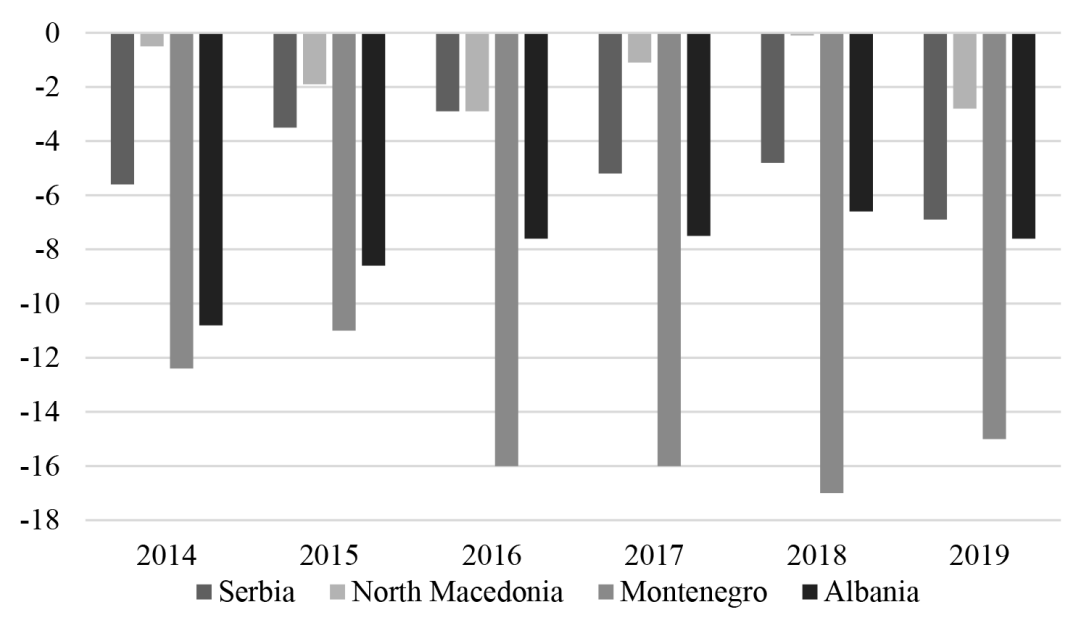

Figure 7. Current account balance as \% of GDP

Source: IMF, 2020

\section{MANAGEMENT TOOLS AND COVID-19 ARGUMENT FOR DIGITALIZATION}

Traditional management tools have evolved in the last few years to the extent that accommodation providers can, aided by technology and digitalization, provide personalised services based on travellers' preferences and needs. Digitalization enables accommodation providers at online platforms to have access to online platform management tools for online booking systems, online payment systems, online financial analytics and online customer relationship systems. For accommodation providers such as households, digital platforms make it possible not just to provide accommodation to tourists and other travellers with the online platforms' support system to manage all phases of tourist services, but to also expand beyond accommodation products to coordinate and facilitate visitor experiences in a destination. These management tools available to accommodation providers are online platforms that act as information brokers and intermediaries (e.g. TripAdvisor, Expedia). On the other hand, digitalization makes it possible for travellers to plan and manage their travels wholly online and while they are already on the way as they can use mobile applications, social media, chatbots, instant advice and the rise of the platform economy in that respect. Travellers can expect that the integration of different applications can make it possible to make changes to bookings on very short notice.

The tourism sector has been hit hard by the outbreak of Covid-19 but in comparison to hotels, accommodation offered by households and individuals has certain advantages. First, tourists and other travellers do not have to meet their hosts or other people because keys for the accommodation can be exchanged in a non-personal way (by leaving them in a designated place). Modern management tools enabled by digitalization do not mean only that check-in/out can be done without a personal contact but also that cashless payment is possible thereby complying with physical distancing requirements. Second, hotels are typically larger and with more guests compared to 
private accommodation provided in detached houses, buildings or bungalows where guests can also prepare their food. Hence, the probability of interacting with other guests in elevators or common areas such as restaurants is very small in accommodations provided by households. Third, hotels usually offer breakfasts and other services (fitness, pools, hairdressers, etc.) that imply larger numbers of people. That is typically not the case in accommodation listed by households at online platforms for short-term tourist stay. Fourth, with the relaxation of travel restrictions, people have started travelling but are still careful. That might mean that travel is mostly local or regional. In the case of the Western Balkans, taking into the account purchasing power of the region, travellers probably wouldn't seek luxury and expensive accommodation. In that respect it has been established that private accommodation listed on online platforms has been, on average, cheaper than hotels (Bivens, 2019). Fifth, the EU's recent pledge for investment in digitalization and reductions in roaming charges for the Western Balkans is an additional argument for further digitalization in the region, especially in this time of uncertainty due to the outbreak of Covid-19.

In sum, in the current and post-corona-virus era, a private accommodation that can be booked online is in a good position to ensure social-distancing and other response measures requested by the authorities. However, accommodation providers need to have not only a connected property but a connected guest as well. That is possible through the use of various technologies. Accommodation providers need to have digital skills to use technology so as to address all tourists' and other travellers' needs and wants. That is especially so if the accommodation is in coastal, rural and mountainous areas that are not hot-tourist spots and have yet not developed to attract large crowds. In the aftermath of the corona virus outbreak, technology is a key enabler.

\section{CONCLUSION}

Western Balkan candidate countries still have a long way on their convergence to the EU average in terms of digitalization and the use of collaborative economy in tourism. The region should increase internet connectivity and also invest in digital skills in order to be able to improve human capital generally, not just in tourism. This is important for both, businesses and households, considering various social and economic challenges in the region.

A reliable and fast internet connection is needed, because the new digital world is entering many aspects of society and economy, including tourism. People use the internet for various reasons and now in the Covid-19 era even more, from sending and receiving emails to making calls (including video calls) over the internet (Viber) and participating in social networks (Facebook, Twitter, Instagram) as well as using instant messaging (exchanging messages via Messanger, WhatsApp, Viber). All of the above has become even more important in times of social distancing requirements and the Covid-19 outbreak. However, in addition to the need of being connected to the internet in these challenging times, the ever-evolving digital technology has had significant effects on consumers' and travellers' behaviour in the last few years. Digitalization is a challenge for traditional business models because "sharing" or "collaborative" economy concept has been embraced by those who see that business model as an opportunity for households and local economies.

Analysis of data in this research shows that Western Balkan countries still have a lot to do to make their economies more competitive, and in terms of digitalization, additional effort should be put into improving internet connectivity and digital skills for the new era. In addition to having a significant economic appeal for candidate countries of Western Balkans, digitalization and investing in digitalization imply further convergence towards the digital single market of the EU. 


\section{REFERENCES}

Bivens, J. (2019). The Economic Costs and Benefits of Airbnb. Economic Policy Institute. Publication. Retrieved from https://www.epi.org/publication/the-economic-costs-and-benefits-of-airbnb-no-reason-for-local-policymakers-to-let-airbnb-bypass-tax-or-regulatory-obligations

Bouwman H. et al. (2017).The Impact of Digitalization on Business Models: How IT Artefacts, Social Media, and Big Data Force Firms to Innovate their Business Model. Econstor. Conference paper. Retrieved from https:/www.econstor.eu/bitstream/10419/168475/1/Bouwman-Reuver-Nikou.pdf

Charalabidis Y. et al (2015). Information Systems in a Changing Economy and Society in the Mediterranean Region. Mediterranean Conference on Information Systems, 2015, Conference Proceedings, AIS Electronic Library. Retrieved from https://aisel.aisnet.org/mcis2015/, p.1-6

Clancy, R (2018). Landlords in London are embracing Airbnb, new research shows. PropertyWire. (website). https://www.propertywire.com/news/uk/landlords-london-embracing-airbnb-new-research-shows/

Dugalić, S. and Lazarević S. (2018). The Digitalization of Active Outdoor Trips in Serbia. Tourism in Function of Development of the Republic of Serbia (pp.290-307). Publisher: University of Kragujevac, Faculty of Hotel Management and Tourism in Vrnjačka Banja

Eurostat (2019). Digital Economy and Society Statistic, Households and Individuals, Statistics Explained. (website). Retrieved from https://ec.europa.eu/eurostat/statistics-explained/pdfscache/33472.pdf

Eurostat (2020a). Glossary: Tourism, Statistics Explained. (website). Retrieved from https://ec.europa.eu/eurostat/statistics-explained/index.php?title=Glossary:Tourism, accessed at February 21,2020

Eurostat (2020b). Glossary: Holiday and Other Short-Term Accommodation. Statistics Explained. (website). Retrieved from https://ec.europa.eu/eurostat/statistics-explained/index.php?title=Glossary:Holiday_and_other_short-stay_accommodation

European Commission (2007). European initiative on an all-inclusive digital society: Frequently Asked Questions. (website). Retrieved from https://ec.europa.eu/commission/presscorner/detail/en/MEMO 07527

European Commission (2018). Strategy for the Western Balkans (website). Retrieved from https:// ec.europa.eu/commission/news/strategy-western-balkans-2018-feb-06_en

European Commission (2019. EU-Western Balkans: Boosting Digital Connectivity. (website). Retrieved from https://ec.europa.eu/digital-single-market/en/news/eu-western-balkans-boosting-digital-connectivity

European Commission (2020). Shaping Europe's Digital Future. (website).Retrieved from https:// ec.europa.eu/info/strategy/priorities-2019-2024/europe-fit-digital-age/shaping-europe-digital-future_en

European Parliament (2019). Contribution to Growth - European Digital Single Market, Delivering improved rights for European citizens and businesses. (website) Retrieved From: https:// www.europarl.europa.eu/RegData/etudes/STUD/2019/638395/IPOL_STU(2019)638395_ EN.pdf. 11-43

Faber and Gaubert (2019). Tourism and Economic Development: Evidence from Mexico's Coastline. American Economic Review 2019, 109(6), p.2245-2293. Retrieved from https://doi. org/10.1257/aer.20161434

Goeroeg C. (2018). The Definitions of Sharing Economy: A Systematic Literature Review. Management. University of Primorska, Faculty of Management Koper, vol. 13(2), 175-189 
International Monetary Fund (2018). Measuring The Digital Economy. Policy paper. (website). Retrieved from https:/www.imf.org/en/Publications/Policy-Papers/Issues/2018/04/03/022818-measuring-the-digital-economy

International Telecommunications Unit. ITU-SG WTPF 13 Information Document 8. World Telecommunications ICT/Policy Forum (2013).Retrieved from https://www.itu.int/md/S13-WTPF13-INF-0008/en

Mao, Y. et al (2018). The Real Effects of Sharing Economy: Evidence from Airbnb. Cornell University School of Hotel Administration, The Scholarly Commons, Working Papers, 3-2018. Retrieved from https://scholarship.sha.cornell.edu/cgi/viewcontent.cgi?article=1051\&contex$\mathrm{t}=$ workingpapers

Marcovitch S. and Willmott P. (2014). Accelerating the digitization of business processes. Mckinsey Digital (website). Retrieved from https://www.mckinsey.com/business-functions/mckinsey-digital/our-insights/accelerating-the-digitization-of-business-processes

Parviainen et al. (2017). Tackling the digitalization challenge: how to benefit from digitalization in practice. International Journal of Information Systems and Project Management, 9 Vol.5, 2017, p.63-77

Sabbagh, K. et al (2013). Digitization for Economic Growth and Job Creation: Regional and Industry Perspectives. The Global Technology Report 2013, World Economic Forum 2013 https:// www3.weforum.org/docs/GITR/2013/GITR_Chapter1.2_2013,p. 35-42

United Nations World Tourist Organization (2019). International Tourism Highlights, 2019 Edition. (website). Retrieved from https://www.e-unwto.org/doi/pdf/10.18111/9789284421152.

United Nations World Tourist Organization (2020). World Tourism Barrometer. Statistical Annex. Volume 18. Issue 2. May 2020. Retrieved from https://webunwto.s3.eu-west-1.amazonaws. com/s3fs-public/2020-05/UNWTO_Barom20_02_May_Statistical_Annex_en_.pdf,

World Travel Tourism Council. 2020. Economic Impact Reports. Retrieved from https://wttc.org/ Research/Economic-Impact 